\title{
Mineral and Metal Levels in Brown Sugar from Organic and Conventional Production Systems
}

\author{
Paulo Dirceu Luchini ${ }^{1}$, Silvia Raquel Bettani ${ }^{2}$, Marta Regina Verruma Bernardi ${ }^{3}$ \\ $\&$ Maria Teresa Mendes Ribeiro Borges ${ }^{3}$ \\ ${ }^{1}$ Department of Rural Development, Federal University of São Carlos School (CCA), Araras, SP, Brazil \\ ${ }^{2}$ Department of Natural Resources and Environmental Protection, Federal University of São Carlos School \\ (CCA), Araras, SP, Brazil \\ ${ }^{3}$ Department of Agroindustrial Technology and Rural Socieconomy, Federal University of São Carlos School \\ (CCA), Araras, SP, Brazil
}

Correspondence: Silvia Raquel Bettani, Department of Natural Resources and Environmental Protection, Federal University of São Carlos School (CCA), Araras, SP, Brazil. E-mail: raquelbettani@gmail.com

Received: March 29, 2017

doi:10.5539/jas.v9n10p226

\author{
Accepted: August 23, $2017 \quad$ Online Published: September 15, 2017 \\ URL: https://doi.org/10.5539/jas.v9n10p226
}

\begin{abstract}
Food and nutrition are basic requirements for the promotion and protection of health. In addition to ensuring the availability of calories for consumption, it is necessary to improve the access to the variety of nutrients offered to the population. The consumption of brown sugar inserts nutrients into the feeding, once it is produced only by the evaporation of the existing water in the sugarcane broth, thus maintaining all the original constituents of the plant. To evaluate the influence of organic and conventional fertilization in the nutritional quality of the brown sugars, a test was conducted with six fertilization systems, in a completely randomized block design with four repetitions. The sugars produced were analysed regarding the contents of the nutrients $\mathrm{Fe}, \mathrm{Zn}, \mathrm{Mn}$ and $\mathrm{Cu}$ and the toxic elements $\mathrm{Pb}$ and $\mathrm{Cd}$. The results showed that the different fertilization systems influenced the content of the minerals present. Although small, the differences were statistically significant and the treatments provided sugars with nutritional characteristics, with an advantage for the totally organic sugar (using organic fertilizer and corrective) which, in addition to environmental issues, did not present lead contamination.
\end{abstract}

Keywords: food safety, organic foods, sugarcane

\section{Introduction}

Agriculture is one of the oldest human activities and is always under transformation (Drew, 2005). Worldwide, from the Green Revolution, the industrialization of agriculture has been using seed cultivation techniques and intensive use of inputs and industrial mechanization seeking to increase agricultural production (Teixeira, 2005).

Industrial agriculture has contributed to numerous forms of environmental degradation, including loss of biodiversity, excessive dependence on non-renewable fossil fuels, soil erosion and air and water pollution caused by the use of fertilizers and pesticides with aggravations to human health. The loss of biodiversity makes this type of agriculture contrary to the basic principles of sustainable development (Horrigan, Lawrence, \& Walker, 2002; Balsan, 2006).

The comparative analysis of production systems leaves no doubt about the problems caused by the conventional system and has shown that the organic farmers who follow an ecological approach have achieved satisfactory results in various aspects related to sustainability. The restoration of the heterogeneity of agricultural habitats and the strengthening of the agricultural biodiversity have also been obtained, being more energetically efficient and producing fewer greenhouse gases (Darolt, 2009).

According to the International Federation of Organic Agriculture Movements [IFOAM] (2008), organic farming is a production system that preserves the health of soils, ecosystems and people. It is based on ecological processes, biodiversity and cycles adapted to local conditions, rather than the use of agrochemicals. Organic farming combines tradition, innovation and science to benefit the environment, sharing and promoting fair relationships and good quality of life for all involved. 
Organic sugar is a product processed according to the international principles of organic agriculture and is certified by the competent entities. In organic sugarcane production, all chemical fertilizers are replaced by integrated organic nutrients to protect the soil and improve their physical and chemical characteristics.

Modern life has caused great changes in our behaviour and eating habits. The change in social, environmental and ethical behaviour of a society avid for healthier foods and whose cultivation systems are less harmful to human health and the environment, has led to a significant increase in the demand for products originating from the agroecological production (Minguetti, 2012). Brown sugar is the product of the evaporation of the sugarcane broth and, since it is not subjected to a refinement process, the naturally occurring mineral salts are maintained in the raw material, meeting these desires (Vieira, 2007; Ministério da Agricultura, Pecuária e Abastecimento [MAPA], 2013).

In this context, Agroecology plays an important role in the transition and formulation of a new science supported on models of rural development and a more sustainable agriculture (Saminêz, Dias, Nobre, Mattar, \& Gonçalves, 2008).

In the recent years, Brazilian organic brown sugar has been featured in the world's largest fairs for organic products such as, for example, the International Fair of Organic Products and Agroecology in 2012, having its production destined for the supply of the population in the form of sweetener and in the food industry in the formulations of foods, such as breads, sweets, jellies and biscuits (Portal da Cidadania, 2012).

Works reported controversies about the quality of foods produced in the organic system compared to the conventional system, mainly for the difficulty in implementing studies where only production systems are the variables (Dangour et al., 2009; Lairon, 2009). The determination of mineral nutrients and inorganic contaminants originating from the organic farming system have an important role in raising data on nutritional quality and the food safety of these products in comparison to the conventional system. The quantification of nutrients and inorganic contaminants has been an additional tool to generate new scientific knowledge on the different food production systems (Silva et al., 2010; Mishra, Mudgal, Madaan, Nudagal, \& Singh, 2010; Yahaya, Aremu, \& Abdullahi, 2012; Dallatu, Abechi, Abba, Mohammed, \& Ona, 2013).

The aim of this study was to quantify the minerals $\mathrm{Cu}, \mathrm{Zn}, \mathrm{Mn}, \mathrm{Fe}$ and the inorganic contaminants $\mathrm{Pb}$ and $\mathrm{Cd}$ in the brown sugar derived from the sugarcane produced by organic and conventional agriculture, where the variable is the production system.

\section{Method}

\subsection{Sugarcane Production}

The study was conducted in the Center of Agricultural Sciences, Federal University of São Carlos, campus Araras-SP. The planting of sugarcane was in April 2009 and the variety used to produce brown sugar was RB 867515. Six treatments were conducted according to the sketch of Figure 1 and Table 1. Each parcel with area of $75 \mathrm{~m}^{2}$ consisted of 5 rows of cane with spacing of $1.5 \mathrm{~m}$ between each other for lengths of $10 \mathrm{~m}$. If the design of the study is complex or the stimuli require detailed description, additional subsections or subheadings to divide the subsections may be warranted to help readers find specific information. 


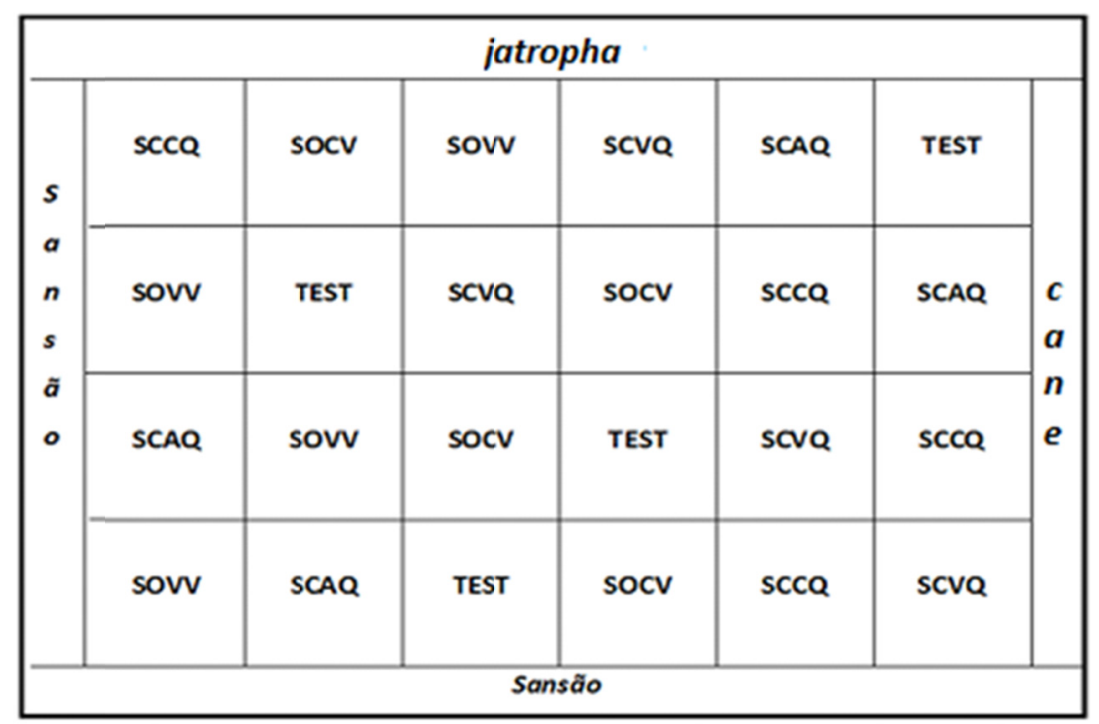

Figure 1. Sugar cane planting Sketch produced in different production systems (organic and conventional)

Table 1. Description of the treatments for the production of sugarcane used to manufacture the brown sugars.

\begin{tabular}{llll}
\hline Treatments & System & Corrective & Fertilizer \\
\hline TEST & Without treatment & & \\
SCVQ & Conventional & Organic $*$ & Mineral \\
SCAQ & Conventional & - & Mineral \\
SCCQ & Conventional & Limestone & Mineral \\
SOCV & Organic & Limestone & Organic * \\
SOVV & Organic & Organic $*$ & Organic $*$ \\
\hline
\end{tabular}

Note. ${ }^{*}$ Visafértil ${ }^{\circledR}$.

The production of brown sugar from these treatments is described in Minguetti (2012). The sugars produced were sifted and packed in polyethylene plastic bags, placed inside polypropylene bottles and stored. The mineral nutrient content and inorganic contaminants were analyzed in the Laboratory of Ecology and Agrochemicals of the Biological Institute (São Paulo, SP).

\subsection{Analysis of Mineral Nutrients and Inorganic Contaminants}

The determination of cadmium and lead was performed in an atomic absorption spectrometer with thermal atomization in graphite furnace GTA 120-GFAA (Varin ${ }^{\circledR}$, model $240 \mathrm{Z}$ ), fitted with Zeeman broker. The determination of zinc, copper, manganese and iron was conducted in an atomic absorption flame spectrometry-FAAS (Perkin-Elmer, model 5110 PC, AA Analyst 200, with high sensitivity nebulizer and impact pearl). When necessary, pre-concentration by complexation with ammonium pyrollidine dithiocarbamate (APDC) into methyl isobutyl ketone (MIBK) was employed.

\subsection{Reagents and Solutions}

The reagents used were of analytical grade and the solutions were prepared with high purity deionized water. To determine the linear range of analysis, calibration curves of the elements in aqueous solution were constructed with increasing concentrations of the reference solutions. For the element $\mathrm{Fe}$, the concentrations varied between 0.1 and $1.0 \mathrm{mg} \mathrm{L}^{-1}$, Mn between 0.1 and $1.0 \mathrm{mg} \mathrm{L}^{-1}$, Cu between 5.0 and $100.0 \mathrm{mg} \mathrm{L}^{-1}$, Zn between 10.0 and $300 \mathrm{mg} \mathrm{L}^{-1}$, for Cd between 0.5 and $10.0 \mathrm{mg} \mathrm{L}^{-1}$ and $\mathrm{Pb}$ between 5.0 and $100.0 \mathrm{mg} \mathrm{L}^{-1}$, obtained by the successive dilution of stock Solutions at $1000 \mathrm{mg} \mathrm{L}^{-1}\left(\mathrm{HNO}_{3} 2 \% \mathrm{v} / \mathrm{v}\right.$-Merck $\left.{ }^{\circledR}\right)$.

The parameters and criteria used in the evaluation of the performance of analytical methods for the quantification of the monitored elements were: linearity of the analytical curve; Detection Limit (LOD), method quantification limit (LOQ) and recovery percentage, according to the document for guidance on the validation of chemical test 
methods by the Instituto Nacional de Metrologia, Normalização e Qualidade Industrial [INMETRO] (2011). For the study of the average recovery, a sample of fortified brown sugar with a standard (multi-element standard, Perkin Elmer) $\mathrm{Cu}, \mathrm{Mn}, \mathrm{Zn}, \mathrm{Fe}, \mathrm{Cd}$ and $\mathrm{Pb}$ was used, at two levels of concentration, which contemplated the interval of the calibration curve of each element analyzed. Obtaining recovery values from 93 to $110 \%$.

\subsection{Sample Processing}

The amount of 1,000 $\mathrm{g}$ of brown sugar from the different treatments and the fortified sample were weighted. They were transferred to a digester tube in a closed system and then there was the addition of $2 \mathrm{ml}$ of ultrapure water, 2 $\mathrm{ml}$ of concentrated $\mathrm{HNO}_{3}$ and the mixture was heated at the temperature of $120^{\circ} \mathrm{C}$ for $2 \mathrm{~h}$. The digested samples were transferred to a volumetric flask and the volume was adjusted to $25 \mathrm{ml}$ with ultrapure water.

\subsection{Statistical Analysis}

The SAS ${ }^{\circledR}$ Software (Institute Inc., 2014) was used for the statistical analysis. The results of the parameters were subjected to variance analysis, when the F test was significant, the results were unfolded and the means of the treatments compared by the Tukey test, to the level of 5\% probability, to identify and compare the difference between treatments.

\section{Results and Discussion}

\subsection{Inorganic Contaminants}

Recommendations of the maximum levels of some inorganic contaminants in foods can be found at the Agência Nacional de Vigilância Sanitária [ANVISA] (2013), and in the African Organisation for Standardisation [ARSO] (2012), which establish as maximum limits for $\mathrm{Pb} 0.1$ and $0.5 \mathrm{mg} \mathrm{kg}^{-1}$, respectively. For cadmium, only ARSO set the maximum limit of $0.05 \mathrm{mg} \mathrm{kg}^{-1}$. The results for the contaminants in this study are presented in Table 2 .

Table 2. Mean values $\left(\mathrm{mg} \mathrm{kg}^{-1}\right)$ of the contents of inorganic contaminants found in the brown sugar

\begin{tabular}{lll}
\hline Treatments & $\mathbf{P b}\left(\mathrm{mg} \mathrm{kg}^{-1} \pm \mathrm{DP}\right)$ & $\mathbf{C d}\left(\mathrm{mg} \mathrm{kg}^{-1} \pm \mathrm{DP}\right)$ \\
\hline TEST & ND & ND \\
SCVQ & $0.30 \pm 0.20 \mathrm{a}$ & ND \\
SCAQ & ND & ND \\
SCCQ & $0.16 \pm 0.03 \mathrm{ab}$ & ND \\
SOCV & $0.20 \pm 0.08 \mathrm{a}$ & ND \\
SOVV & ND & ND \\
\hline
\end{tabular}

Note. Means with the same letters, in the column, do not differ significantly at $5 \%$ probability by analysis of variance ANOVA-Tukey test. $\mathrm{ND}=$ not detected.

TEST: Absolute witness; SCVQ: Conventional system with organic corrective and mineral fertilizer; SCAQ: Conventional system without corrective and with mineral fertilizer; SCCQ: Conventional system with limestone correction and mineral fertilizer; SOCV: Organic system with limestone correction and organic fertilizer; SOVV: Organic system with corrective and organic fertilizer.

The Brazilian legislation does not establish a maximum limit of tolerance for Cd in sugars (ANVISA, 2013), while ARSO (2012) determines the ceiling of $0.05 \mathrm{mg} \mathrm{kg}^{-1}$. According to the results obtained, no cadmium was detected in any of the different brown sugar production systems. Waheed, Rahman, and Gill (2009), who used instrumental analysis by neutron activation (INAA) in brown sugar samples, also did not detect any Cd contamination.

Lead contamination may derive from several sources, among which: atmospheric deposition; application of corrective, fertilizer and agrochemicals; irrigation water and by the addition of organic and inorganic residues (Tavares, 2010). A study conducted by Wilwerth et al. (2009) with different brown sugar brands found $\mathrm{Pb}$ concentrations in the order of 6.3 to $16.2 \mathrm{mg} \mathrm{kg}^{-1}$.

In this study, treatments SCVQ, SCCQ and SOCV presented $\mathrm{Pb}$ concentrations higher than the maximum limit for sugars in Brazil $\left(0.1 \mathrm{mg} \mathrm{kg}^{-1}\right)$ varying between $0.16-0.30 \mathrm{mg} \mathrm{kg}^{-1}$; these levels have no significant difference between them and their consumption may pose a risk to human health. These levels were lower than those found by Faria (2012) in his study with organic brown sugar, where $\mathrm{Pb}$ concentration was in the order of $0.69 \mathrm{mg} \mathrm{kg}^{-1}$. In the other treatments, the presence of $\mathrm{Pb}$ was not detected. 


\subsection{Mineral Nutrient}

The contents of the mineral nutrients $\mathrm{Cu}, \mathrm{Zn}, \mathrm{Mn}$ and $\mathrm{Fe}$ found and the recommendation, tolerance intake and nutritional composition of foods are presented in Table 3.

Table 3. Nutrient contents found in the brown sugar samples of the different treatments $\left(\mathrm{mg} \mathrm{kg}^{-1} ; \mathrm{n}=6\right)$

\begin{tabular}{|c|c|c|c|c|c|c|c|c|c|}
\hline & TEST & SCVQ & SCAQ & SCCQ & SOCV & SOVV & $\mathrm{TACO}^{1}$ & ANVISA $^{2}$ & $\mathrm{WHO}^{3}$ \\
\hline & \multicolumn{6}{|c|}{ - mg kg \pm DP } & $\mathrm{mg} 100 \mathrm{~g}^{-1}$ & \multicolumn{2}{|c|}{------ $\mathrm{mg}_{\mathrm{day}}{ }^{-1}$------ } \\
\hline $\mathrm{Cu}$ & $1.58 \pm 0.09^{\mathrm{c}}$ & $1.95 \pm 0.06^{\mathrm{b}}$ & $2.13 \pm 0.04^{\mathrm{a}}$ & $2.13 \pm 0.08^{\mathrm{a}}$ & $1.97 \pm 0.08^{\mathrm{b}}$ & $1.38 \pm 0.05^{\mathrm{d}}$ & 0.17 & 0.9 & 10 \\
\hline $\mathrm{Zn}$ & $5.72 \pm 0.15^{\mathrm{c}}$ & $5.76 \pm 0.12 b^{\mathrm{c}}$ & $5.89 \pm 0.14^{\mathrm{ab}}$ & $5.99 \pm 0.10^{\mathrm{a}}$ & $5.71 \pm 0.07^{\mathrm{c}}$ & $4.90 \pm 0.13^{\mathrm{d}}$ & 0.5 & 7 & 45 \\
\hline $\mathrm{Mn}$ & $18.43 \pm 0.28^{b}$ & $15.41 \pm 0.11^{\mathrm{d}}$ & $20.46 \pm 0.54^{\mathrm{a}}$ & $15.69 \pm 0.15^{\mathrm{d}}$ & $15.85 \pm 0.27^{\text {cd }}$ & $15.33 \pm 0.28^{\mathrm{d}}$ & 2.03 & 2.3 & 11 \\
\hline $\mathrm{Fe}$ & $14.28 \pm 0.55^{\mathrm{c}}$ & $16.95 \pm 0.80^{\mathrm{b}}$ & $19.01 \pm 0.95^{\mathrm{a}}$ & $14.31 \pm 0.39^{\mathrm{c}}$ & $15.20 \pm 0.75^{\mathrm{c}}$ & $12.35 \pm 0.47^{\mathrm{d}}$ & 8.3 & 14 & 45 \\
\hline
\end{tabular}

Note. Means with equal letters do not differ significantly at $5 \%$ probability by analysis of variance ANOVA-Tukey test.

TEST: Absolute witness; SCVQ: Conventional system with organic corrective and mineral fertilizer; SCAQ: Conventional system without corrective and with mineral fertilizer; SCCQ: Conventional system with limestone correction and mineral fertilizer; SOCV: Organic system with limestone correction and organic fertilizer; SOVV: Organic system with corrective and organic fertilizer.

${ }^{1}$ Tabela Brasileira de Composição de Alimentos [TACO], (2011);

${ }^{2}$ Recommended Daily Intake-RDI (ANVISA, 2005);

${ }^{3}$ Upper Limit for Tolerable Intake-UL (World Health Organization [WHO], 2006).

In general, there is a deficiency of guidelines and standardisation on quantity, recommended and tolerable limits for ingestion of various nutrients and toxic substances for populations, with a view that the guidelines differ between countries and many of them do not have recommendations (ANVISA, 2005; WHO, 2006; ARSO, 2012).

According to ANVISA (2005), Cu DRI is $0.9 \mathrm{mg} \mathrm{day}^{-1}$. WHO (2006) establishes the maximum tolerable intake limit-UL $10 \mathrm{mg} \mathrm{day}^{-1}$, whereas ARSO (2012) restricts the tolerable daily intake to $0.1 \mathrm{mg} \mathrm{day}^{-1}$.

TACO (2011) presents the value of $1.7 \mathrm{mg} \mathrm{kg}^{-1} \mathrm{Cu}$ in sugar. In the study of Wilwerth et al. (2009) 31 brands of commercial brown sugars were analysed and the $\mathrm{Cu}$ content varied between 0.2 and $13.3 \mathrm{mg} \mathrm{kg}^{-1}$. In this study, the lowest $\mathrm{Cu}$ contents were found for the SOVV treatment $\left(1.38 \mathrm{mg} \mathrm{kg}^{-1}\right)$, followed by TEST $\left(1.58 \mathrm{mg} \mathrm{kg}^{-1}\right)$. The treatments SCVQ and SOCV did not differ statistically (1.95 and $1.97 \mathrm{mg} \mathrm{kg}^{-1}$ ), being lower than SCAQ and SCCQ $\left(2.13 \mathrm{mg} \mathrm{kg}^{-1}\right)$, the latter being the largest $\mathrm{Cu}$ contents obtained in the experiment. Very close values are observed between the treatments SCVQ, SOCV, SCAQ and SCCQ, despite the statistical difference, and their values were higher than those reported by TACO. It was found that the samples of brown sugar from all production systems studied are below the Cu DRI, which is $0.9 \mathrm{mg} \mathrm{day}^{-1}$ (ANVISA, 2005), and below the maximum tolerable intake limit-UL of $10 \mathrm{mg} \mathrm{day}^{-1}$ (WHO, 2006), being safe for human consumption, exceeding only the maximum tolerance limit established by ARSO (2012), which is $0.1 \mathrm{mg} \mathrm{day}^{-1}$, considering a daily intake of $100 \mathrm{~g}$ of sugar.

In relation to the levels of $\mathrm{Zn}$, ANVISA recommends the daily intake of $7 \mathrm{mg}$ and WHO recommends a tolerable ceiling of $45 \mathrm{mg} \mathrm{day}^{-1}$. The Food Composition Table (TACO) presents, as the mean Zn value in brown sugar, $5 \mathrm{mg}$ $\mathrm{kg}^{-1}$. Waheed and Ahamad (2008) analyzed the $\mathrm{Zn}$ content in brown sugar samples collected in Pakistan and obtained average levels of $3.4 \mathrm{mg} \mathrm{kg}^{-1}$. In this work the $\mathrm{Zn}$ values found in the samples of sugar produced by TEST, SCVQ, SOCV, SCAQ, SCCQ and SOVV presented statistical differences between the organic and conventional production systems, the values staying between 4.90 and $5.99 \mathrm{mg} \mathrm{kg}^{-1}$; therefore, the $\mathrm{Zn}$ contents are close to the value recommended by TACO (2011). Assuming a diet with 100 g.day $^{-1}$ of sugar, the $\mathrm{Zn}$ content ingested is approximately 0.49 to $0.60 \mathrm{mg}$. Therefore, it is below the DRI of Zn $\left(7 \mathrm{mg}^{-1 a y^{-1}}\right)$ and the tolerable limit $(45 \mathrm{mg}$ day $^{-1}$ ).

The daily Mn intake recommended by ANVISA is $2.3 \mathrm{mg} \mathrm{day}^{-1}$ and WHO recommends the maximum tolerable intake limit-UL of $11 \mathrm{mg}$. On average, according to TACO, $20 \mathrm{mg} \mathrm{kg}^{-1}$ of Mn is present in brown sugar.

In the studies conducted by Waheed and Ahmad (2008) using INAA in the determination of Mn in brown sugar, they obtained an average content of $3.7 \mathrm{mg} \mathrm{kg}^{-1}$, whereas Wilwerth et al. (2009) used the technique of Plasma Emission Spectrometry (ICP) in determining mineral nutrients in brown sugar and detected Mn between 2.1 and 
$56.2 \mathrm{mg} \mathrm{kg}^{-1}$. In this work the concentrations found ranges from 15.33 to $20.46 \mathrm{mg} \mathrm{kg}^{-1}$ of $\mathrm{Mn}$ and did not differ significantly in the samples SCVQ, SOCV SCCQ and SOVV. However, for samples of brown sugar TEST and SCAQ, Mn levels were higher when compared with the other treatments; for treatment SCAQ, the result is equivalent to that presented in the TACO and the others are a little inferior. Assuming a daily intake of $100 \mathrm{~g}$ of brown sugar, treatment SCAQ supplies the need and the others reach a very close level and all would be below the maximum tolerable daily limit (WHO, 2006), being therefore safe for human health.

The recommendation for daily intake of Fe by ANVISA is $14 \mathrm{mg}$ and the maximum tolerable intake limit-UL recommended by WHO is $45 \mathrm{mg}$ day $^{-1}$. TACO presents, as the medium content found in brown sugar, $83 \mathrm{mg} \mathrm{kg}^{-1}$.

In the studies conducted by Waheed and Ahmad (2008) and Faria (2012) the values found for Fe in brown sugar were similar, 52.1 and $53.4 \mathrm{mg} \mathrm{kg}^{-1}$, respectively. In this study, the results obtained vary between 12.35 and 19.01 $\mathrm{mg} \mathrm{kg}^{-1}$, presenting significant differences between them. Treatment SCAQ presented the highest value, followed by SCVQ. Treatments TEST, SCCV and SOCV showed no significant difference from each other and differed from SOVV, which presented the lowest value. All treatments obtained Fe values below TACO. Considering a daily intake of $100 \mathrm{~g}$ of brown sugar, all treatments obtained an Fe content less than the intake recommended by ANVISA.

Menezes, Giuntini, and Lajolo (2003) reported that variations in nutrient content of foods are normal and occur depending on the variety of plants, crops, soil, climate, production, formulation and analytical quality even in the detection of these nutrients. Apparently other conditions such as soil, climate and variety have influenced more than the production systems studied.

In the study, despite the statistical differences between the composition of the nutrients and the type of planting (conventional or organic), it was observed that the values obtained are different from other authors, as well as from those recommended by TACO; therefore, variations in the nutrient content of the foods occur not only by the way of cultivation, but also by the soil, climate, culture, among other variables.

Additional studies must be performed to evaluate and monitor the mineral nutrient content and inorganic contaminants of brown sugar produced from sugarcane cultivated in different production systems.

\section{Conclusion}

In general, sugars from the conventional and organic systems presented differences between the composition of the mineral nutrients $\mathrm{Cu}, \mathrm{Zn}, \mathrm{Mn}$ and $\mathrm{Fe}$, and the treatment with organic system using corrective and organic fertilizer presented the lowest values (SOVV), whereas the Conventional system with no corrective and with mineral fertilizer (SCAQ) had the highest nutritional values. In all treatments evaluated, the levels are lower than the values of daily intake recommended by ANVISA (2005). However, with full condition of contributing to the nutritional quality, complementing man's intake of nutrients such as $\mathrm{Cu}, \mathrm{Zn}, \mathrm{Mn}$ and $\mathrm{Fe}$.

No treatment produced Cd contamination. Regardless of the form of cultivation (conventional or organic), there were treatments with contamination by $\mathrm{Pb}$ in concentrations above the maximum values allowed by the Brazilian legislation, and treatments that did not present contamination by $\mathrm{Pb}$, with an advantage for the organic sugar (SOVV), which contributes to environmental issues.

The values obtained in the study differ from those obtained by other authors, as well as from those recommended by TACO, and it is concluded that variations in the nutrient content of foods occur not only in the form of cultivation, but also by the soil, climate, culture, among others.

\section{Acknowledgements}

Prof. Dr. Luiz Carlos Luchini and Prof. Dr. Mara M. Andrea, Laboratory of Ecology and Agrochemistry of the Biological Institute of São Paulo, availability of equipment for the analysis of mineral nutrients and inorganic contaminants.

\section{References}

African Organisation for Standardisation (ARSO). (2012). Brown Sugars: Specification. Nairobi: African Organisation for Standardisation.

Agência Nacional de Vigilância Sanitária (ANVISA). (2005). Resolução RDC $n^{\circ} 269$, de 22 de setembro de 2005. DOU 23/09/05. Aprova o "regulamento técnico sobre a Ingestão Diária Recomendada (IDR) de proteina, vitaminas e minerais". Retrieved from http://coffito.gov.br/nsite/wp-content/uploads/2016/08/ resoluo-rdc-n-269-2005-ingesto-diria-recomendada-idr-de-protenas-vitaminas-e-minerais.pdf 
Agência Nacional de Vigilância Sanitária (ANVISA). (2013). Resolução RDC n. 42, de 29 de agosto de 2013. Retrieved from http://bvsms.saude.gov.br/bvs/saudelegis/anvisa/2013/rdc0042_29_08_2013.html

Balsan, R. (2006). Impactos decorrentes da modernização da agricultura brasileira. Campo-território: Revista de Geografia Agrária, 1(2), 123-151.

Dallatu, Y. A., Abechi, S. E., Abba, H., Mohammed, U. S., \& Ona, E. C. (2013). Level of heavy metal in fresh and canned foods consumed in North Central Nigeria. Scholarly Journal of Agricultural Science, 3(6), 210-213.

Dangour, A. D., Dodhia, S. K., Hayter, A., Allen, E., Lock, K., \& Uauy, R. (2009). Nutritional quality of organic foods: A systematic review. The American Journal of Clinical Nutrition, 92(1), 203-210. https://doi.org/ 10.3945/ajen.2010.29269

Darolt, M. R. (2009). Comparação entre a qualidade do alimento orgânico e a do convencional. In P. C. Strigheta, \& J. N. Muniz (Eds.), Alimentos orgânicos: Produção, tecnologia e certificação (pp. 289-312). Viçosa, MG: UFV.

Drew, D. (2005). Processos interativos homem-meio ambiente (6th ed.). Rio de Janeiro, RJ: Bertrand.

Faria, D. A. M. (2012). Estudo nutricional e sensorial de açúcar cristal, refinado, demerara e mascavo orgânico e convencional (Master's thesis, Universidade Federal de São Carlos, São Carlos, Brasil). Retrieved from https://repositorio.ufscar.br/bitstream/handle/ufscar/121/4492.pdf?sequence=1

Horrigan, L., Lawrence, R. S., \& Walker, P. (2002). How sustainable agriculture can address the environmental and human health harms of industrial agriculture. Environental Health Perspectives, 110(5), 445-456. https://doi.org/10.1289/ehp.02110445

Instituto Nacional de Metrologia, Normalização e Qualidade Industrial (INMETRO). (2011). Orientações sobre validação de métodos de ensaios químicos: Documento de caráter orientativo (4th ed.). Rio de Janeiro, RJ: Instituto Nacional de Metrologia, Normalização e Qualidade Industrial. Retrieved from http://www.inmetro.gov.br/Sidoq/Arquivos/CGCRE/DOQ/DOQ-CGCRE-8_04.pdf

International Federation of Organic Agriculture Movements (IFOAM). (2008). Definition of organic agriculture. Retrieved from http://www.ifoam.org/en/organic-landmarks/definition-organic-agriculture

Lairon, D. (2009). Nutritional quality and safety of organic food: A review. Agronomy Sustainable Development, 30(1), 33-41. https://doi.org/10.1051/agro/2009019

Menezes, E. W., Giuntini, E. B., \& Lajolo, F. M. (2003). A questão da variabilidade e qualidade de dados de composição de alimentos. Revista da Sociedade Brasileira de Alimentação e Nutrição, 2, 63-76.

Minguetti, F. F. (2012). Influência dos sistemas de produção, convencional e orgânico, na qualidade da cana-de-açúcar (Saccharum sp.) e do açúcar mascavo (Master's thesis, Universidade Federal de São Carlos, Araras, Brasil). Retrieved from https://repositorio.ufscar.br/bitstream/handle/ufscar/147/4963.pdf?sequence $=1 \&$ isAllowed $=\mathrm{y}$

Ministério da Agricultura, Pecuária e Abastecimento (MAPA). (2013). Portaria n. 990 de 11 de outubro de 2013. Retrieved from http://www.lex.com.br/legis_24942451_PORTARIA_N_990_DE_11_DE_OUTUBRO_DE _2013.aspx

Mishra, S., Mudgal, V., Madaan, N., Nudagal, A., \& Singh, R. B. (2010). Effect of toxic metals on human health. The Open Nutraceuticals Journal, 3, 94-99. https://doi.org/10.2174/18763960010030100094

Portal da Cidadania. (2012). Açúcar mascavo orgânico brasileiro é destaque na Biofach 2012. Retrieved from http://portal.mda.gov.br/biofach/news/item?item_id=9311814

Saminêz, T. C. O., Dias, R. P., Nobre, F. G. A., Mattar, R. G. H., \& Gonçalves, J. R. A. (2008). Princípios norteadores da produção orgânica de hortaliças. Brasília, DF: Embrapa Hortaliças. Retrieved from https://www.embrapa.br/busca-de-publicacoes/-/publicacao/773407/principios-norteadores-da-producao-org anica-de-hortalicas

SAS Institute Inc. (2014). SAS/STAT: 9.1 User's guide. Cary, NC: SAS Institute Inc.

Silva, C. S., Nunes, P. O., Mescouto, C. S. T., Muller, R. C. S., Palheta, D. C., \& Fernandes, K. G. (2010). Avaliação do uso da casca do fruto e das folhas de Caesalpinia férrea Martius como suplemento nutricional de Fe, Mn e Zn. Ciência e Tecnologia de Alimentos, 30(3), 751-754. https://doi.org/10.1590/S010120612010000300028 
Tabela Brasileira de Composição de Alimentos (TACO). (2011). Tabela Brasileira de Composição de Alimentos (4th ed.). Campinas, SP: NEPA-UNICAMP.

Tavares, A. D. (2010). Determinação de cádmio e chumbo em alimentos e bebidas industrializados por espectrometria de absorção atômica com atomização eletrotérmica (Doctoral dissertation, Universidade Federal da Paraíba, João Pessoa, Brasil). Retrieved from http://www.quimica.ufpb.br/posgrad/teses/ Tese_Adriano_Duarte_Tavares.pdf

Teixeira, J. C. (2005). Modernização da agricultura no Brasil: Impactos econômicos, sociais e ambientais. Revista Eletrônica da Associação dos Geógrafos Brasileiros, 2(2), 21-42.

Vieira, M. C. A. (2007). Setor sucroalcooleiro brasileiro: Evolução e perspectivas. Brasília, DF: BNDES. Retrieved from http://www.bndes.gov.br/SiteBNDES/export/sites/default/bndes_pt/Galerias/Arquivos/conh ecimento/liv_perspectivas/07.pdf

Waheed, S., \& Ahmad, S. J. (2008). Instrumental neutron activation analysis of different products from the sugarcane industry in Pakistan-Part 1: Essential elements for nutritional adequacy. Journal of AOAC International, 91(2), 392-399.

Waheed, S., Rahman, S., \& Gill, K. P. (2009). INAA and AAS of different products from sugar cane industry in Pakistan: Toxic trace elements for nutritional safety. Journal of Radioanalytical and Nuclear Chemistry, 279(3), 725-731. https://doi.org/10.1007/s10967-008-7332-2

Wilwerth, M. W., Silva, C.V. N., Lopes, C. H., Souza, G. B., Bernardi, A. C. C., Borges, M. T. M. R., \& Verruma-Bernardi, M. R. (2009). Determinação de minerais e metais pesados em açúcar mascavo. Anais do Congresso de Iniciação Cientifica, 17, \& Jornada Científica da UFSCar, 8, 94. Retrieved from https://www.alice.cnptia.embrapa.br/alice/bitstream/doc/660023/1/PROCI2009.00328.pdf

World Health Organization (WHO). (2006). Guidelines on food fortification with micronutrients. Geneva: World Health Organization. Retrieved from http://apps.who.int/iris/bitstream/10665/43412/1/9241594012_eng.pdf

Yahaya, D. B., Aremu, D. A., \& Abdullahi, I. (2012). Investigation of metal contaminants in locally ground foods (beans and tomatoes). Journal of Emerging Trends in Engineering and Applied Sciences (JETEAS), 3(1), 339-343. Retrieved from http://jeteas.scholarlinkresearch.com/articles/Investigation\%20of $\% 20 \mathrm{Metal} \% 20$ Contaminants\%20in\%20Locally\%20Ground\%20Foods\%20(Beans\%20and\%20Tomatoes).pdf

\section{Copyrights}

Copyright for this article is retained by the author(s), with first publication rights granted to the journal.

This is an open-access article distributed under the terms and conditions of the Creative Commons Attribution license (http://creativecommons.org/licenses/by/4.0/). 